\title{
Evaluating the learning by development action model with CS students.
}

\author{
LINTILÄ, T.
}

2021

Permission to make digital or hard copies of all or part of this work for personal or classroom use is granted without fee provided that copies are not made or distributed for profit or commercial advantage and that copies bear this notice and the full citation on the first page. Copyrights for components of this work owned by others than ACM must be honored. Abstracting with credit is permitted. To copy otherwise, or republish, to post on servers or to redistribute to lists, requires prior specific permission and/or a fee. Request permissions from permissions@acm.org. 


\title{
Evaluating the Learning by Development Action Model with CS Students
}

\author{
Taina Lintilä \\ School of Computing \\ Robert Gordon University \\ Aberdeen, United Kingdom / \\ Haaga-Helia University of Applied Sciences \\ Helsinki, Finland \\ t.lintilae@rgu.ac.uk
}

\begin{abstract}
The purpose of the study is to find out how the competence of computing students develops throughout a study module as they are exposed to a Learning by Developing (LbD) Action Model. Furthermore, their perception of the model is evaluated against existing pedagogies to better understand the effectiveness of this tool when used specifically in a CS context.
\end{abstract}

\section{CCS CONCEPTS}

- Computer and Education: Computer and Information Science Education $\rightarrow$ computer science education

\section{KEYWORDS}

Software engineering, computer science, computing, teaching and learning methods, learning by developing

\section{ACM Reference format:}

Taina Lintilä. 2021. Evaluating the Learning by Development Action Model with CS Students. In 26th ACM Conference on Innovation and Technology in Computer Science Education V. 2 (ITiCSE 2021), fune 26-fuly 1, 2021, Virtual Event, Germany. ACM, New York, NY, USA, 2 pages. https://doi.org/10.1145/3456565.3460020

\section{Context and Motivation}

The purpose of this research is to collect and analyze information on the use of the Learning by Developing (LbD) action model from computing study modules in two different higher education institutions: Laurea University of Applied Sciences (Laurea) in Finland and Robert Gorfon University (RGU) in the UK. All stakeholders involved in each study module are invited to participate in the study, so that the experiences of students, project clients and academic lecturers are captured and analysed. A purpose-built survey is used to capture initial response to the LbD action model by the various stakeholders within the context of the study module within which it was used. Furthermore, the study also aims to obtain information about the development of

Permission to make digital or hard copies of part or all of this work for personal or classroom use is granted without fee provided that copies are not made or distributed for profit or commercial advantage and that copies bear this notice and the full citation on the first page. Copyrights for third-party components of this work must be honored. For all other uses, contact the Owner/Author.

ITiCSE 2021, June 26-fuly 1, 2021, Virtual Event, Germany

(C) 2021 Copyright is held by the owner/author(s). students' competence during the study module and about their experiences of using $\mathrm{LbD}$ as a teaching and learning method. Research material is also collected from clients through interviews on how well LbD fit into their projects.

With the rapid increase of work-based learning [1], there is a need to evaluate appropriate tools for this kind of pedagogical instruction. The research is based on the need for organizations to develop pedagogical models to better meet the needs of working life.

\section{Literature Review}

Learning by Developing (LbD), based on developmental learning, is a pragmatic learning concept. John Dewey (Learning by Doing) emphasizes the closeness and learning of the school as a tool that produces new forms of action as a continuous interaction between human and the environment. The LbD Action Model is central to the development of new ways of working and the renewal of working life. The pragmatic concept of learning focuses on collaboration, individual and environmental change, and the importance of experience and interaction (Figure 1). LbD emphasizes active learning, and considers how the learning experience can lead to new ways of working [2].

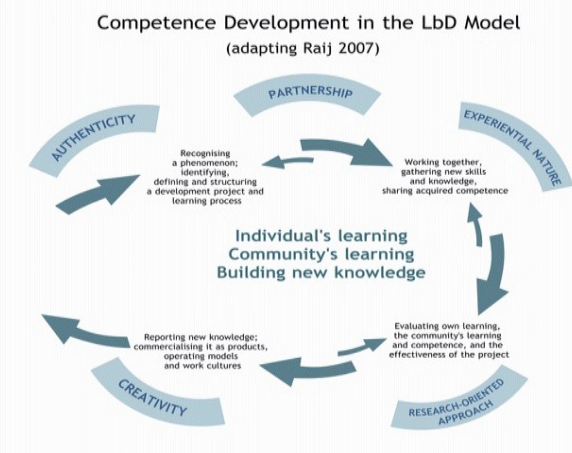

Figure 1: Competence Development in the LbD Action Model

The LbD action model was initially developed by closely examining teaching and learning in different Universities of Applied Sciences [2]. The LbD Action Model has been used at since 2004 and has been shown to be a successful way to teach 
new things in higher education [3]. Studies on LbD-based learning at Laurea University of Applied Sciences have been conducted among students in social sciences and health care, but not very comprehensively among computing students.

Background research has alreary done in Laurea were the research data was collected by interviews from Laurea's LbD experts [4]. Background research at Laurea was a very important starting point for the research. An expert in pedagogy at RGU will also be interviewed in order to find out the initial situation at RGU.

\section{Problem Statement}

The LbD Action Model has been used at Laurea University of Applied Sciences, and is ingrained within the institutional pedagogy. Its suitability for the development of students' competences, specifically from the point of view of the skills needed in working life, has been significant. However, only a small amount of research data is available for computing students. The aim of this study is to research the use of LbD in an international context. The international pilot study is carried out within the School of Computing at the Robert Gordon University in the UK, where students are used to working with real-world clients within their project-based modules. The presence of multiple stakeholders (client, student, lecturer) provides a good starting point for piloting LbD in these study modules.

\section{Research Goals}

The goal of the research is to obtain information on the suitability of LbD within a CS context. Information is collected and analyzed at both Laurea (the originating institution) and RGU (the pilot institution) to better understand any benefits afforded by this Action Model, as well as to identify any potential areas for development for $\mathrm{LbD}$.

\section{Research Methods}

The strategy of this research has been chosen as action research because it is well suited for development-based research, where the researcher is him/herself part of the organization being developed. Action research is a discipline-based research conducted by a teacher, the purpose of which is to obtain information and, on the basis of the information received, to change his or her practice in the future [5]. In this process, participants systematically and carefully review their own teaching practices using research methods [6]. Action research is well-suited to educational research and can involve just a single teacher, a group of teachers with a common problem, or the entire school faculty [7].

Action research proceeds periodically, starting from the situation under study. Based on the information being researched, the researcher gets a picture of the current state and on the basis of it, he or she sets out to plan the target state. The researcher participates in the development process, reflects on the situation with other participants and further develops it.
This project has consisted of multiple cycles: the first cycle was conducted at Laurea in the autumn of 2019 with a further cycle being planned with staff and students from RGU. This institution was initially chosen to ascertain whether the $\mathrm{LbD}$ approach is also suitable for computing students within a more international context, where LbD was not a well-established pedagogical tool. Method triangulation is used as the main research method in this study. Method triangulation means that several data acquisition methods are used in the acquisition of research material [7]. The data collection methods used in this study include a survey conducted for students and a thematic interview conducted for lecturers and clients. As a method of analysing research data, datadriven content analysis is used for thematic interviews and freeform questions from students. When conducting data-based research, the main emphasis of the research is on the data, which means that the analysis units are not pre-determined and the theory is built on the data as a starting point. In this case, one can speak of inductance, which means the progression from individual observations to more general claims [8]. The starting point of the inductive approach is therefore not the testing of theory or hypotheses, and the researcher does not determine what is important [9]. Students' quantitative responses are initially analysed using means and standard deviations.

\section{Contributions}

The research results provide information on the suitability of LbD as a teaching and learning method for computing students. The results are collected and analyzed in two different higher education institutions: Laurea in Finland and RGU in the UK. At Laurea, LbD is an established pedagogical model, but at RGU it is being piloted for the first time. This therefore gives great opportunity for the further development of LbD - other than understanding its benefits within a CS-specific context, at Laurea, the research results can be used in the development of $\mathrm{LbD}$, and at $\mathrm{RGU}$, one can consider whether LbD should be included as one of the institution's pedagogical approaches. The study also provides information on how students' competences develop in study modules in which LbD is used as a teaching and learning method.

\section{REFERENCES}

[1] Work-based learning. 2021. European Training Foundation https://www.etf.europa.eu/en/practice-areas/work-based-learning.

[2] Raij, K. 2007. Learning by Developing. Vantaa. Laurea.

[2] Raij, K. 2012. Summarising the basis of LbD for further development - review. Laurealaisella väylällä.

[4] Lintila, T \& Zarb, M. 2020. Analysing the Learning by Developing Action Model in HE Computing. In Conference Proceedings (2020 IEEE Frontiers in Education Comperence).

[5] Ferrance, E. 2000. Action Research. Themes in Education. Northeast and Islands Regional Education Laboratory. Brown University.

[6] Taber, K.S. 2013. Action Research and the Academy: seeking to legitimize a 'different' form of research Teacher Development, 17(2), pp. 288-300.

[7] Sagor, R. 2000. Guiding School Improvement with Action Research. Association for Supervision and Curriculum Development. Alexandria. USA.

[8] Eskola, J \& Suoranta, J. 2005. Johdatus laadulliseen tutkimukseen. 7. painos. Tampere. Vastapaino.

[9] Hirsjärvi, S., Remes, P \& Sajavaara, P. Tutki ja kirjoita. 2004. 10 osin uud. laitos. Helsinki. Tammi. 